\title{
The Impact of Using Inverted Classrooms on Promoting Extensive versus Intensive Reading Comprehension among Iranian Upper- intermediate EFL Learners
}

\author{
Leila Neisi \\ Department of English Language, Faculty of Humanities, Ahvaz Branch, Islamic Azad University, Ahvaz, Iran \\ Mehrnnoosh Hajijalili \\ Department of English, Faculty of Humanities, Shahrekord Branch, Islamic Azad University, Shahrekord, Iran \\ Ehsan Namaziandost \\ Department of English, Faculty of Humanities, Shahrekord Branch, Islamic Azad University, Shahrekord, Iran
}

\begin{abstract}
This study aimed to investigate the impact of inverted classrooms on promoting Iranian EFL learners' extensive and intensive reading comprehension. To fulfil, 60 Iranian upper-intermediate EFL students out of 90 were chosen based on an Oxford Quick Placement Test. The selected participants were randomly divided into two experimental groups; intensive reading group $(n=20)$ and extensive reading group $(n=20)$, and a control group $(n=20)$. Then, the three groups were pretested. After that, the researcher put the participants of both experimental groups in two inverted classrooms. Each inverted classroom was equipped with Internet, computer and projector and participants in this classroom were allowed to bring their Smartphones to the classroom and use them during learning. On the other hand, the control group receive no treatment and were taught in traditional instruction. The results of paired samples t-test and one-way ANOVA revealed that both experimental groups had better performance on their post-test compared to their pre-test. The results showed that there was not a significant difference between the performances of the experimental groups on the post-test. Finally, implications arising from the findings and suggestions for further research were explained.
\end{abstract}

Index Terms —inverted classrooms, extensive reading, intensive reading

\section{INTRODUCTION}

As inverted or flipped models have turned out to be progressively common in the instructional writing and more extensively actualized by experts in the course of recent years (Moranski and Kim, 2016), the need to research the impacts of flipped study halls on language learning is critically significant. The flipped study hall is an academic system that switches the conventional homeroom process by conveying the instructional substance as a rule, however not constantly, online before class and after that drawing in students in intuitive gathering learning or potentially basic critical thinking exercises that are completed under the educators' direction during class (Herreid \& Schiller, 2013).

Flipped classroom are accepted to be helpful for educating and learning. Some instructive advantages of the flipped study hall were dictated by certain analysts. These advantages incorporate (1) understudies and teachers' certain impression of the dynamic learning condition (e.g., Namaziandost \& Nasri, 2019; Gilboy, Heinerichs, \& Pazzaglia, 2015), (2) increasingly dynamic commitment during class (e.g., Namaziandost, Nasri, \& Rahimi Esfahani, 2019), and (3) predominant accomplishment on developmental/summative evaluations (e.g., Amresh, Carberry, \& Femiani, 2013). For instance, when Love, Hodge, Grandgenett, and Swift (2014) executed a flipped straight polynomial math course, most of understudies announced that the methodology helped them build up a more profound comprehension of the substance. Amresh et al. (2013) detailed that understudies in a flipped early on PC programming course performed fundamentally superior to did understudies in a practically identical conventional course plan on assignments and tests.

The instructive significance of the flipped study hall is upheld by a scope of understudy focused learning speculations in the field of instructive brain research (Bishop and Verleger, 2013), including helpful learning (Namaziandost, Ahmadi, \& Keshmirshekan, 2019), collaborative learning (Nasri, Biria, \& Karimi, 2018), peer tutoring (Namaziandost \& Ahmadi, 2019), peer assisted learning (Nasri \& Biria, 2017), problem-based learning (Azadi, Biria, \& Nasri, 2018), and active learning (Michael, 2006; Abedi, Keshmirshekan, \& Namaziandost, 2019).

As of late, the improvement of instructive innovation has permitted flipped study halls to be effectively embraced in advanced education settings (Hosseini, Nasri, \& Afghari, 2017). This learning condition can be described as understudy 
focused - understudies are required to come to class having just picked up the information important to effectively participate in critical thinking exercises with their friends. All through the cycle of guidance, they keep up a functioning job at the focal point of learning. The training depends on the presumptions that important collaboration among companions supports information building and that instructors can give all the more auspicious and customized direction and input during in-class exercises (Kim, Park, Jang, \& Nam, 2017; Namaziandost, Rahimi Esfahani, Nasri, \& Mirshekaran, 2018).

Extensive reading contrasts from concentrated reading. In serious reading, understudies regularly work with short messages with close direction from the educator. The point of concentrated reading is to enable understudies to acquire definite significance from the content, to create reading aptitudes, for example, distinguishing fundamental thoughts and perceiving content connectors - and to improve jargon and sentence structure learning. Note that these two ways to deal with showing reading — concentrated and broad reading — ought not be viewed as being in resistance, as both fill diverse yet correlative needs (Carrell \& Carson 1997; Namaziandost, Abedi, \& Nasri, 2019). Be that as it may, serious reading is by all accounts the overwhelming method of showing reading in numerous language homerooms. This is in spite of proof that escalated reading alone won't enable students to build up their reading familiarity, a significant expertise that develop readers get simply after rehashed introduction to huge amounts of composed content.

\subsection{Research Questions}

This study aimed to answer the following research questions:

RQ1. Do inverted classrooms significantly affect Iranian EFL learners' extensive reading comprehension?

RQ2. Do inverted classrooms significantly affect Iranian EFL learners' intensive reading comprehension?

\subsection{Research Null Hypotheses}

Based on the above-mentioned research questions, the following null hypotheses were tested:

HO1. Inverted classrooms do not significantly affect Iranian EFL learners' extensive reading comprehension.

RQ2. Inverted classrooms do not significantly affect Iranian EFL learners' intensive reading comprehension.

\section{REVIEW OF THE LITERATURE}

\section{A. The Flipped Classroom}

The "flipped classroom" is another catchphrase in training, however it's anything but a totally original thought. Educators frequently allot reading to be done at home, and afterward anticipate that understudies should participate in discussion about the reading in class. This plan could be named a modified study hall (Strayer, 2012). Notwithstanding, a couple of key qualities recognize the flipped study hall from a transformed study hall. In the flipped homeroom, understudies watch video-recorded talks outside of class, therefore expanding time for dynamic learning and practice to happen in class (Namaziandost, Nasri, \& Rahimi Esfahani, 2019). While execution of this technique may appear to be somewhat unique for every instructor, basically "the 'flipped' some portion of the flipped study hall implies understudies watch or tune in to exercises at home and get their 'work done' in class" (Fulton, 2012, p. 13).

Web based learning has different definitions. Verifiably, video talks were made to give educational program access to people who lived a long way from school. Educators started acknowledging recordings offed site understudies, yet in addition understudies who were available during talks (Hashemifardnia, Namaziandost, \& Sepehri, 2018). Online classes picked up notoriety in the previous decade, particularly at the school level. Nonetheless, understudies usually whined about restricted collaboration and correspondence in absolutely online classes (Gecer \& Dag, 2012). Flipping the study hall includes web-based learning through a progression of video addresses, however it is bolstered by up close and personal study hall discourses and individual assistance. In this way, the flipped study hall is not quite the same as conventional internet learning situations.

Customary homeroom addresses frequently pursue a one-pace-fits-all way of thinking. Educators may alter their talks dependent on the understudies' criticism, yet a few understudies will without a doubt discover the pace quick, while others think that its moderate. Video talks gave through the flipped study hall model enable understudies to quick advance through models they as of now comprehend, or delay and rewind to return to subjects which may require all the more handling time (Goodwin \& Miller, 2013). Recordings enable talks to be broken into pieces, instead of conventional guidance which regularly contains an enormous volume of substance conveyed at once (Mirshekaran, Namaziandost, \& Nazari, 2018).

Khan (2012), a generally perceived online instructor, promoted the flipped homeroom through his site, Khan Academy. This site contains more than 4,120 short instructive recordings, most itemizing a particular math idea (Thomas, 2013). Khan chips away at the issues bit by bit on every video. "Khan's thought was that adolescents would watch the recordings at home and work on the issues in class, basically 'flipping' the study hall" (Kronholz, 2012, p. 25). Understudies likewise visit the site to get schoolwork help when they are stuck on the issue. Khan looks to change the manner in which individuals consider instruction, noticing "the old homeroom model just doesn't accommodate our evolving needs" (Khan, 2012, p. 1).

Numerous schools have utilized Khan's recordings to flip the study hall. Greg Green, head at Clintondale Community Schools in Michigan, praised the flipped homeroom for its capacity to help understudies who don't get schoolwork help at home (Finkel, 2012). Understudies presently get direction at home as video addresses, and can legitimately interface with instructors and companions during class time to find solutions to their inquiries. Educators using Khan Academy to 
flip their homerooms acknowledge they frequently work more earnestly during the school day as they are continually moving near and interfacing with understudies. It must be noted Khan Academy isn't implied as a fix-all. Math educator Courtney Cadwell remarked Khan "isn't incredible at helping children conceptualize math" (Kronholz, 2012, p. 26). Video talks should be enhanced with exercises which energize exchange and accentuate the application side of science. When flipping the homeroom, instructors should continually communicate with understudies, alter guidance on the fly, and plan exercises which supplement the recordings.

\section{B. Extensive Reading}

As indicated by Carrell and Carson (1997), extensive reading... for the most part includes quick reading of enormous amounts of material or longer readings (for example entire books) for general comprehension, with the emphasis for the most part on the importance of what is being perused than on the language. While this definition gives a review of broad reading, Davis (1995) offers a progressively valuable meaning of extensive reading from a study hall execution point of view: "A extensive reading system is a beneficial class library plot, connected to an English course, in which understudies are since time is running short, support, and materials to peruse pleasurably, at their very own level, the same number of books as they can, without the weights of testing or checks" (p. 68). Consequently, understudies are contending just against themselves, and it is dependent upon the instructor to give the inspiration and observing to guarantee that the most extreme number of books is being perused in the time accessible. The watchwords are amount and assortment, as opposed to quality, with the goal that books are chosen for their appeal and significance to the students' lives, as opposed to for scholarly merit (Namaziandost, Nasri, \& Keshmirshekan, 2019).

Albeit extensive reading projects go under various names, including Uninterrupted Sustained Silent Reading (USSR), Drop Everything and Read (DEAR), and Silent Uninterrupted Reading for Fun (SURF), and the Book Flood program (Elley \& Mangubhai, 1983; Tahmasbi, Hashemifardnia, \& Namaziandost, 2019), they all offer a typical reason: that students read enormous amounts of books and different materials in a domain that supports a deep rooted reading propensity. Moreover, these projects additionally share a typical conviction, that is, the capacity to peruse easily is best accomplished through reading broadly in the language.

\section{Intensive Reading}

Intensive reading as a philosophy is an educator focused methodology, which means the teacher coordinates the vast majority of what occurs in class, including what to peruse, when to peruse, and what jargon, language structure, content association or perception focuses are to be examined. Contingent upon the educator, a great part of the clarification for these focuses might be done in Japanese. Presumably, understudies are urged to pose inquiries, yet without such interest by understudies, the instructor establishes the tone and picks which parts of the content are to get examination. Second language (L2) proficiency research underpins serious reading as a technique, especially as it applies to jargon improvement (Nation, 1993).

Dark colored (2007) considered escalated reading classes as a spot where base up and top-down handling are utilized intelligently to accomplish reading appreciation. At the end of the day, consideration ought to be given to phoneme, root and word acknowledgment to advance toward significance (base up) just as to the (top-down) procedure of beginning with foundation information and general importance and working from that point to increasingly explicit cognizance. As a major aspect of the top-down procedure, he supported abilities building and familiarity works out, for example, distinguishing the reason for reading, skimming, checking, speculating from setting, semantic mapping, and sort contemplates (Namaziandost, Nasri, Rahimi Esfahani, \& Keshmirshekan 2019).

While there are demonstrated advantages to a serious reading philosophy, specialists have additionally referred to certain negatives. The inclination to concentrate on sentence level linguistic structure can turn an ostensible "reading" class into a language class. There is, obviously, not much with showing language, yet it just isn't equivalent to "reading" (Nasri, Namaziandost, \& Akbari, 2019; Susser \& Robb, 1990). Country (2009) questions whether serious reading educators are picking their writings with the end goal of making consequent writings intelligible. On the off chance that the picked reading entry is loaded with low-recurrence words, at that point the understudy will encounter minimal future profit by the exertion put in to understand it. The inclination to concentrate on interpretation of sentences or entries is another tricky territory. One would need to scan long and hard for a solitary proficiency pro who supporters sentence or entire section interpretation as a proficient utilization of time in an EFL reading class. At last, the concentrated examination of all parts of a solitary, short reading entry-generally one that was not picked by the reader - can make the reading procedure appear to be repetitive and add to the frequently heard understudy abstain that reading in English is troublesome or on the other hand exhausting. Nuttal (1996) depicted the endless loop of the powerless reader," alluding to the procedure of the constrained, slow, worked reading of troublesome entries, prompting reading shirking, with the end goal that little improvement in perception during a course is accomplished.

\section{Empirical Background}

Some studies have been conducted on flipped classroom to measure its effects. For instance, Johnson and Jeremy Runner (2012) contemplated the impact of the flipped homeroom model on an auxiliary PC applications course: understudy and educator recognitions, questions and understudy accomplishment. The discoveries showed that no advantage to utilizing the flipped study hall guidance in an optional PC application. Robert Overmyer (2014) examined 
the flipped study hall model for school variable based math: consequences for understudy accomplishment. The discoveries of this examination demonstrate that there was not a factually huge distinction in the scores of understudies in the two gatherings; nonetheless, understudies in the flipped segments showed improvement over the understudies in the customary areas.

Ching Lin and Chen (2016) expected to check and to comprehend the impacts of flipped study hall on the learning adequacy, while utilizing learning fulfillment as the arbiter. The discoveries demonstrated that: 1) both the educators and understudies of specialized and professional schools (the principal half) accepted that flipped learning positively affects learning fulfillment; while the understudies of the second $50 \%$ of specialized a professional universities accepted that flipped learning negatively affects learning fulfillment; 2) both the teachers and understudies of specialized and professional universities (the two parts) accepted that flipped learning has a noteworthy constructive outcome on learning viability; and 3) both the teachers and understudies of specialized and professional universities (the main half) accepted that flipped learning positively affects learning adequacy; while the educators and understudies of the second $50 \%$ of specialized and professional schools accepted that flipped learning negatively affects learning viability. Abridging the abovementioned, learning fulfillment has a halfway intervening impact.

Kim, Park, Jan, and Nam (2017) researched the psychological impacts of the flipped study hall approach in a substance based instructional setting by looking at second language students' talk in flipped versus conventional homerooms as far as (1) cooperation rate, (2) substance of remarks, (3) thinking abilities, and (4) interactional examples. Students in two flawless classes took an interest and were educated in either a flipped classroom(n=26) or a conventional homeroom $(n=25)$. In the flipped class, the students tuned in to an online talk before class and partook in a little bunch exchange in class. Conversely, the students in the conventional class tuned in to an instructor drove address in class and after that promptly took an interest in a little bunch dialog in class. The students' discourses were sound recorded. Quantitative and subjective examinations demonstrated no distinction in cooperation rates; nonetheless, the understudies in the flipped homeroom created progressively intellectual remarks including further data handling and higher-request reason in $\mathrm{g}$ abilities and indicated more strong interactional examples than did the understudies in the customary study halls. The outcomes showed that flipped study halls can successfully advance higher-request thinking forms and inside and out, strong talk in the substance based second language.

\section{METHOD}

\section{A. Participants}

The participants of this study are 60 upper-intermediate language learners who were selected among 90 EFL learners at a private English language institute in Ahvaz, Iran. The participants' age range was from 19 to 21 . They were selected based on non-random sapling. Moreover, they have been studying English as a foreign language for at least five years. Their level of English language proficiency was determined on the basis of their scores on the Oxford Quick Placement Test (OQPT). The learners were randomly divided into two experimental groups; Intensive Reading Group (IRG) Extensive Reading Group (ERG), and a Control Group (CG). Only males were participated in the current study.

\section{B. Instruments}

The first instrument which was used in the present study to homogenize the participants is the OQPT. It helped the researcher to have a greater understanding of what level (i.e., elementary, pre-intermediate, intermediate, upperintermediate, and advanced) his participants were at. According to this test, the learners whose scores were between 38 and 49 (out of 60) were considered as the upper-intermediate learners.

The second instrument was an extensive/intensive reading pre-test. To realize the current participants' reading comprehension level, a researcher-made pre-test was designed based on the students' materials (Interchange 2). It was a reading comprehension test of 40 objective items including short answer and true or false items. The validity of the pretest was confirmed by two English experts. It was piloted on a similar group from another institute. It should be mentioned that the reliability index of the pre-test was calculated through KR-21 formula as it was $r=.982$.

The third instrument of the current study was two post-tests of extensive/intensive reading. After the treatment, an extensive reading post-test was designed and given to the ERG. It included 40 objective items including short answer and true or false items. Like the pre-test, validity of the post-test was confirmed by two English experts. It will be piloted on a similar group from another institute. The reliability index of this test was computed through KR-21 formula as it was $r=.839$. The other post-test was an intensive reading test which was given to the IRG. It was similar to the post-test mentioned above. It had 40 objective items including short answer and true or false items. Similarly, this posttest was validated by two English experts and it was piloted on a similar group from another institute. The reliability index of this test was computed through KR-21 formula and it was $r=.799$.

\section{Data Collection Procedure}

To conduct the present study, the researcher gave OQPT to 90 Iranian EFL students to determine their level of English proficiency. The researcher selected 60 upper-intermediate students and divided them randomly into two experimental groups; intensive reading group $(n=20)$ and extensive reading group $(n=20)$, and a control group ( $n=20)$. Then, all groups were pretested. After that, the researcher puts the participants of IRG and ERG in two flipped 
classrooms. Each flipped classroom was equipped with Internet, computer and projector and participants in this classroom were allowed to bring their Smartphones to the classroom and used them during learning. The students in the flipped classrooms were given 12 reading texts (6 intensive reading texts were given to the IRG and 60 extensive reading texts were given to the ERG) from Interchange 2. Each text was sent to the students via Email, What's App or Telegram to the students. The students were required to read each text before coming the class and discussed it with the classmates. In the class, the teacher could elicit some information from the students, asked them some questions or give them a test. He could also ask them to read a text and say its main idea. The control group receive no treatment and was taught through traditional instruction. The treatment lasts 12 sessions of 60 minutes each under the guidance of the supervisor. In the last session, both groups took the post-tests of extensive/intensive reading.

\section{Data Analysis Procedure}

In data analysis, firstly, Shapiro-Wilk test was used to check the normality of the gathered data. Then, the descriptive statistics were calculated through using SPSS software, version 25. Finally, paired samples t-test and One-way ANOVA were run to determine the effectiveness of flipped classrooms on Iranian EFL learners' reading comprehension.

\section{RESUlTS AND DiSCUSSION}

The primary outcomes are introduced and showed dependent on the inquiries of the investigation. The information acquired from the pre-/post-trial of the perusing understanding tests were dissected and translated utilizing the Statistical Package for the Social Sciences (SPSS). The outcomes were utilized to respond to the examination questions.

TABLE 1.

SHAPIRO-WILK TEST (GROUPS' PRETESTS AND POST-TESTS)

\begin{tabular}{cccc}
\hline & \multicolumn{3}{c}{ Shapiro-Wilk } \\
\cline { 2 - 4 } & Statistic & $\mathrm{df}$ & Sig. \\
\hline IRG. Pretest & .843 & 20 & .004 \\
\hline IRG. Posttest & .886 & 20 & .022 \\
\hline ERG. Pretest & .898 & 20 & .037 \\
\hline ERG. Posttest & .896 & 20 & .034 \\
\hline CG. Pretest & .921 & 20 & .103 \\
\hline CG. Posttest & .853 & 20 & .006 \\
\hline
\end{tabular}

Note. IRG (Intensive Reading Group); ERG: Extensive Reading Group, CG: Control Group

The $\mathrm{p}$ esteems under the Sig. segment in Table 1 decide if the appropriations were typical or not. A p esteem more noteworthy than .05 demonstrates a typical dispersion, while a p worth lower than .05 shows that the circulation has not been ordinary. Since all the p esteems in Table 1 were bigger than .05 , it could be presumed that the conveyances of scores for the pretest and posttest acquired from the two gatherings had been typical. It is hence protected to continue with parametric test (for example Combined examples t-tests and single direction ANOVA for this situation) and make further examinations between the taking an interest groups.

TABLE 2.

DESCRIPTIVE STATISTICS RESUlts COMPARING IRG, ERG, AND CG MEAN SCORES ON THE PRETEST

\begin{tabular}{|c|c|c|c|c|c|c|c|c|}
\hline & \multirow[t]{2}{*}{$\mathrm{N}$} & \multirow[t]{2}{*}{ Mean } & \multirow{2}{*}{ Std. Deviation } & \multirow[t]{2}{*}{ Std. Error } & \multicolumn{2}{|c|}{$95 \%$ Confidence Interval for Mean } & \multirow{2}{*}{ Minimum } & \multirow[t]{2}{*}{ Maximum } \\
\hline & & & & & Lower Bound & Upper Bound & & \\
\hline IRG & 20 & 14.60 & 1.16 & .26 & 14.05 & 15.14 & 13.00 & 17.50 \\
\hline ERG & 20 & 14.70 & .96 & .21 & 14.24 & 15.15 & 13.50 & 16.50 \\
\hline $\mathrm{CG}$ & 20 & 14.92 & 1.04 & .23 & 14.43 & 15.41 & 13.00 & 16.50 \\
\hline Total & 60 & 14.74 & 1.05 & .13 & 14.47 & 15.01 & 13.00 & 17.50 \\
\hline
\end{tabular}

Table 2 shows the mean scores of the learners in the IRG $(M=14.60)$, ERG $(M=14.70)$, and CG $(M=14.92)$. To find out whether the differences among these three mean scores were statistically significant or not, the researcher had to examine the $p$ value under the Sig. column in the ANOVA table. In this table, a $p$ value less than .05 would indicate a statistically significant difference among the four groups, while a $p$ value larger than .05 indicates a difference which failed to reach statistical significance.

TABLE 3.

RESUlTS OF ONE-WAY ANOVA COMPARING THE PRETEST SCORES OF IRG, ERG, AND CG

\begin{tabular}{cccccc}
\multicolumn{5}{c}{ RESULTS OF ONE-WAY ANOVA COMPARING THE PRETEST SCORES OF IRG, ERG, AND CG } \\
\hline Sum of Squares & df & Mean Square & F & Sig. \\
\hline Between Groups & 1.10 & 2 & .55 & .49 & .61 \\
\hline Within Groups & 64.13 & 57 & 1.12 & \\
\hline Total & 65.24 & 59 & & \\
\hline
\end{tabular}

Based in the information presented in Table 3, there was not a statistically significant difference in the pretest scores for the IRG $(M=14.60, S D=1.16)$, ERG $(M=14.70, S D=.96)$, and CG $(M=14.92, S D=1.04), p=.61$ (two-tailed). 
This conclusion was made since the $p$ value was larger than the significance level $(p>.05)$. Hence, it could be inferred that the learners in the three groups, two groups of experimental and control group, were at the same in pretest.

The main objective of the study was to find out whether using inverted classroom affected the intensive or extensive reading. For this purpose, the posttest reading scores of the IRG, ERG and CG needed to be compared via one-way between-groups ANOVA. The results of the comparison of the three groups on the posttest are displayed in Tables 4., 5., and 6.

TABLE 4.

DESCRIPTIVE STATISTICS RESUlts COMPARING IRG, ERG, AND CG MEAN SCORES ON THE POSTTEST

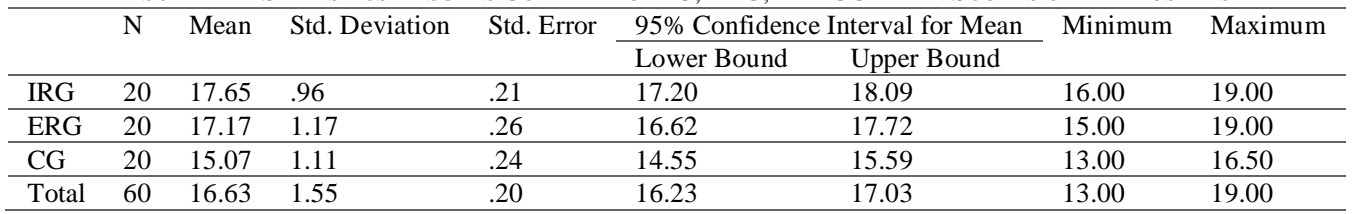

The mean scores of the CG $(M=15.07)$, ERG $(M=17.17)$, and IRG $(M=17.65)$ were found to be different from one another on the delayed posttest. To find out whether the differences among these mean scores were of statistical significance or not, one needs to examine the $p$ value under the Sig. column in the ANOVA table below (Table 5).

TABLE 5.

RESUlTS OF ONE-WAY ANOVA COMPARING THE POSTTEST SCORES OF IRG, ERG, AND CG

\begin{tabular}{cccccc}
\hline & Sum of Squares & df & Mean Square & F & Sig. \\
\hline Between Groups & 75.10 & 2 & 37.55 & 31.79 & \\
\hline Within Groups & 67.32 & 57 & 1.18 & & \\
\hline Total & 142.43 & 59 & & \\
\hline
\end{tabular}

As is could be observed in Table 5, there was a statistically significant difference in the delayed posttest scores for CG $(M=15.07, S D=1.11)$, ERG $(M=17.17, S D=1.17)$, and EG2 $(M=17.65, S D=.96)$ on the posttest of reading since the $p$ value under the Sig. column was found to be less than the specified level of significance (i.e. $.000<.05$ ), meaning that the three groups significantly differed in terms of reading performance. This result could also be clearly noticed in the bar chart that follows (Figure 4.2).

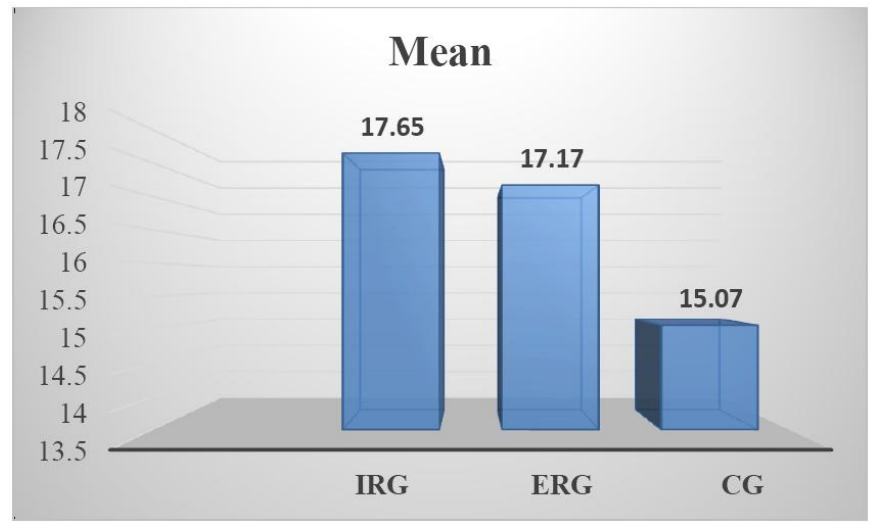

Figure 4.2: The mean scores of CG, ERG, and IRG on the posttest

It is clear that IRG learners managed to get higher scores than did ERG learners, who in turn, could obtain higher scores than the CG learners. Pair-wise comparisons of the groups (in Table 6.) reveals which two groups were significantly different on the posttest.

TABLE 6.

RESUlts OF THE SCHEFFE POSt Hoc TeST FOR COMPARING CG, ERG, AND IRG MEAN SCORES ON THE POSTTEST

\begin{tabular}{|c|c|c|c|c|c|c|}
\hline \multirow[t]{2}{*}{ Groups } & \multirow[t]{2}{*}{ Groups } & \multirow{2}{*}{$\begin{array}{c}\text { Mean } \\
\text { Difference }\end{array}$} & \multirow[t]{2}{*}{ Std. Error } & \multirow[t]{2}{*}{ Sig. } & \multicolumn{2}{|c|}{$95 \%$ Confidence Interval } \\
\hline & & & & & Lower Bound & Upper Bound \\
\hline \multirow[t]{2}{*}{ IRG } & ERG & .47 & .34 & .39 & -.38 & 1.33 \\
\hline & $\mathrm{CG}$ & 2.57 & .34 & .00 & 1.71 & 3.43 \\
\hline \multirow[t]{2}{*}{ ERG } & IRG & -.47 & .34 & .39 & -1.33 & .38 \\
\hline & $\mathrm{CG}$ & 2.10 & .34 & .00 & 1.23 & 2.96 \\
\hline \multirow[t]{2}{*}{$\mathrm{CG}$} & IRG & -2.57 & .34 & .00 & -3.43 & -1.71 \\
\hline & ERG & -2.10 & .34 & .00 & -2.96 & -1.23 \\
\hline
\end{tabular}

In the top row, the comparison of ERG $(M=17.17)$ and IRG $(M=17.65)$ revealed that the both intensive and extensive reading were affected by using inverted classroom and no significant difference observed due to the fact that the $p$ value corresponding to the comparison of these two experimental groups (i.e. .39) exceeded the significance level. 
Likewise, CG learners' mean score CG $(M=15.07)$ was significantly lower than that of IRG learners $(M=17.65)$ because of the fact that the $p$ value related to this comparison was .00 , which is lower than the significance level. As a result, it could be inferred that the using inverted classroom led to a significant effect on EFL learners' intensive reading.

Finally, it could be seen that the difference between CG $(M=15.07)$ and ERG $(M=17.17)$ was statistically significant since the Sig. value corresponding to this comparison $(p=.000)$ was less than .05 . This means that using inverted classroom could lead to a significant effect on the EFL learners' extensive reading.

To get sure about whether using inverted classroom had significant effects on intensive/extensive reading of upper intermediate Iranian EFL learners. the pretest and posttest scores of the learners in the all groups were compared by means of a paired-samples $t$ test:

TABLE 7.

RESUlts OF THE PAIRED-SAMPLES T Test COMPARING PRETEST AND POSTTEST SCORES OF THE IRG, ERG, AND CG

\begin{tabular}{|c|c|c|c|c|c|c|c|c|c|}
\hline & & \multicolumn{5}{|c|}{ Paired Differences } & \multirow[t]{3}{*}{$\mathrm{t}$} & \multirow[t]{3}{*}{$\mathrm{df}$} & \multirow{3}{*}{$\begin{array}{l}\text { Sig. (2- } \\
\text { tailed) }\end{array}$} \\
\hline & & \multirow[t]{2}{*}{ Mean } & \multirow[t]{2}{*}{$\begin{array}{c}\text { Std. } \\
\text { Deviation }\end{array}$} & \multirow[t]{2}{*}{$\begin{array}{l}\text { Std. Error } \\
\text { Mean }\end{array}$} & \multicolumn{2}{|c|}{$\begin{array}{l}\text { 95\% Confidence Interval of the } \\
\text { Difference }\end{array}$} & & & \\
\hline & & & & & Lower & Upper & & & \\
\hline $\begin{array}{c}\text { Pair } \\
1\end{array}$ & $\begin{array}{l}\text { IRG. Post - } \\
\text { IRG. Pre }\end{array}$ & 3.05 & 1.31 & .29 & 2.43 & 3.66 & 10.35 & 19 & .00 \\
\hline $\begin{array}{c}\text { Pair } \\
2\end{array}$ & $\begin{array}{l}\text { ERG. Post - } \\
\text { ERG. Pre }\end{array}$ & 2.47 & 1.68 & .37 & 1.68 & 3.26 & 6.58 & 19 & .00 \\
\hline $\begin{array}{c}\text { Pair } \\
3\end{array}$ & $\begin{array}{l}\text { CG. Post - } \\
\text { CG. Pre }\end{array}$ & .15 & .28 & .06 & .01 & .28 & 2.349 & 19 & .06 \\
\hline
\end{tabular}

Table 7 uncovered that there was a measurably noteworthy distinction between the pretest and posttest scores of the IRG students since the $\mathrm{p}$ esteem under the Sig, (2-followed) section was littler than the noteworthiness level (for example $.00<.05$ ). This demonstrates the treatment (utilizing rearranged homeroom) was compelling so far as the escalated perusing of the Iranian upper middle of the road EFL students were concerned.

Moreover, the difference between the post-test and pre-test of the extensive group is significant since Sig (.00) is less than 0.05 . it can be concluded that, like IRG, using inverted classroom improved the extensive reading of the Iranian upper intermediate EFL learners.

Looking at the third pair, it shows the difference between pretest and posttest of control group is not significant since the $p$ value under the Sig, (2-tailed) column was higher than the significance level (i.e. .06 >.05).

In summary, after collecting the data, the researcher analyzed them in order to find out the effectiveness of inverted classrooms on the students' intensive and extensive reading comprehension. The findings showed that the students who received instruction through inverted classrooms had better performance compared to those who were trained through traditional classrooms (CG). The results statistically revealed that both intensive and extensive groups significantly did better than the control group $(\mathrm{p}<.05)$. Therefore, both null hypotheses of the study "inverted classrooms do not significantly affect Iranian EFL learners' extensive and intensive reading comprehension" were rejected. Participants in the inverted classrooms were highly motivated to learn because of the available facilities. Inverted learning is generally found to increase motivation (Bormann, 2014; Keshmirshekan, Namaziandost, \& Pournorouz, 2019). Not only did they enjoy learning, but also, they felt satisfied with what they learned. In fact, the experimental groups gained higher scores on their post-test. This may be due to some appealing features the inverted classrooms have. The inverted class can be more interactive than the traditional lecture; it can encourage contacts between students and teachers; it can develop reciprocity and cooperation among students, and it can emphasize time on task. As the researcher observed, in the inverted classroom, during class time, students engaged in discussions, activities, problem solving, and group work. Since students had prior knowledge, they could learn the lesson more easily.

The acquired outcomes are in accordance with Hashemifardnia, Namaziandost, and Shafiee who researched the impact of executing flipped study halls on Iranian middle school understudies' perusing cognizance. To this end, 50 Iranian pre-middle of the road understudies were choosen and arbitrarily relegated into two equivalent gatherings; one test gathering (flipped study hall) and one control gathering (conventional homeroom). From that point forward, the two gatherings were pretested through a perusing appreciation test. At that point, the specialists put the respondents of the trial bunch in a flipped study hall. The flipped study hall was outfitted with Internet, PC and projector. The understudies were required to peruse every content before coming the class and talk about it with their colleagues. Then again, the control gathering was educated in the conventional study hall. Prior to showing every content, the analysts gave foundation learning to the control gathering and subsequent to showing every content, the understudies were required to respond to certain inquiries identified with the content. The entire treatment endured 8 sessions of 50 minutes. In the last session, the post-trial of perusing understanding was regulated. The aftereffects of combined and autonomous examples t-tests demonstrated that there was a noteworthy distinction between the post-trial of the exploratory and the control gatherings. The discoveries uncovered that the test bunch altogether outflanked the control gathering $(\mathrm{p}<.05)$ on the post-test.

In addition, these discoveries are in accordance with the discoveries of different specialists, for example, Schmidt (1990) contended that consideration and unequivocal educating are vital for learning and Villa (1994) concentrated on the origination of consideration and its impact on the second language advancement. 
The fundamental finding of this investigation is that the utilization of the flipped training system without a doubt can possibly assist educators with improving their learning results in the innovation coordination course. This advantage showed measurably noteworthy contrasts in learning results between understudies instructed by flipped and talk based showing methodologies, with the most astounding scores accomplished by understudies in the flipped condition and the least in the talk-based condition. The consequences of the present examination bolster past discoveries delivered with regards to other substance regions and with various populace and give exact proof that approves the flipped instructing methodology to improve understudies' learning results (Sadaghiani, 2012; Sparks, 2013; Walker,2011).

This noteworthy finding may be because of various reasons. One of the potential clarifications for the watched outcomes is that transformed study halls empower understudies to profit more from homeroom time and possess more energy for communication, learning, evaluation, and investigation (Fulton, 2012 and to Boucher, Robertson, Wainner, and Sanders 2013). The discoveries of the present examination in this regard are as per those of Hung (2015) who found that flipped instructional model in English classes builds up understudies' scholarly exhibition when all is said in done.

\section{CONCLUSION}

Generally speaking, the results showed that Iranian EFL learners can benefit from attending inverted classrooms. Based on the findings of the present study, it can be concluded that the implementing of inverted classrooms in teaching and learning can produce positive results because they could absorb students in learning English. The positive effects of using inverted classrooms became obvious after the treatment. Here, it can be claimed that receiving instruction through using inverted classrooms can facilitate English learning. inverted classrooms can make the students independent and help them learn how to study out of the classroom. To wind up self-coordinated students, understudies must figure out how to survey the requests of the assignment, assess their very own insight and abilities, plan their methodology, screen their advancement, and modify their techniques as required flipped talk keeps an eye on part aptitude and gives the chances to evaluate, apply and examine recently procured learning. With respect to viability and significance of the flipped homerooms, they are prescribed to be actualized in instructive conditions. In this investigation, flipped study halls had a few advantages for the understudies; these advantages might be owing to the official direction dependent on information mapping that were set up before class through pre-learning.

\section{REFERENCES}

[1] Abedi, P., Keshmirshekan, M. H., \& Namaziandost, E. (2019). The comparative effect of flipped classroom instruction versus traditional instruction on Iranian intermediate EFL learners' English composition writing. Journal of Applied Linguistics and Language Research, 6(4), 43-56.

[2] Alderson, J. C. (2000). Assessing reading. Cambridge: Cambridge University Press.

[3] Amresh, A., Carberry, A. R., \& Femiani, J. (2013). Evaluating the effectiveness of flipped classrooms for teaching CS1. In 2013 IEEE Frontiers in Education Conference (pp. 733-735). Oklahoma City: IEEE.

[4] Azadi, G., Biria, R., \& Nasri, M. (2018). Operationalising the Concept of Mediation in L2 Teacher Education. Journal of Language Teaching and Research, 9(1), 132-140.

[5] Bakshi, S. (2015). Flipped classrooms. Teacher: The Professional Development Community for Educators, 9(3), 13-24.

[6] Bennett, B., Kern, J., Gudenrath, A. \& McIntosh, P. (2011, June 23). The Flipped Class: What Does a Good One Look Like? Retrieved August 15, 2019 from http://www.thedailyriff.com/articles/the-flipped-class-what-does-a-good-one-look-like692.php.

[7] Bergmann, J. (2012). Flip your classroom: Reach every student in every class every day. Alexandra, VA: International Society for Technology in Education.

[8] Bishop, J. L., \& Verleger, M. A. (2013). The flipped classroom: A survey of research. 120thASEE annual conference and exposition. Retrieved August 2, 2019 fromhttp://www.asee.org/public/conferences/20/papers/6219/view.

[9] Block, E. (2004). The comprehension strategies of second language readers. TESOL Quarterly, 20(3), 463-494.

[10] Bormann, J. (2014). Affordances of flipped learning and its effects on student engagement and achievement, University of $\begin{array}{lllll}\text { Northern } & \text { Iowa. } & \text { Retrieved } & \text { August } & 15,\end{array}$ http://fln.schoolwires.net/cms/lib07/VA01923112/Centricity/Domain/41/bormann_lit_review.pdf.

[11] Boucher, B., Robertson, E., Wainner, R. \& Sanders, B. (2013). "Flipping” Texas State University's physical therapist musculoskeletal curriculum: Implementation of a hybrid learning model. Journal of Physical Therapy Education, 27(3), 72-77.

[12] Brantmeier, C. (2005). Effects of readers' knowledge, text type and test type on L1 and L2 reading comprehension in Spanish. The Modern Language Journal, 8(9), 37-53.

[13] Brown, H. D. (2004). Language assessment: Principles and classroom practices. U.S.A: Longman.

[14] Brown, H.D. (2007). Teaching by principles, an interactive approach to language pedagogy, third edition. 360; $366-367$. Pearson-Longman.

[15] Carrell, P.L., \& Carson, J.G. (1997). Extensive and intensive reading in an EAP setting. English for Specific Purposes, 1(6), 47-60.

[16] Ching Lin, p., \& Chen, H. (2016). The effects of flipped classroom on learning effectiveness: using learning satisfaction as the mediator. World Transactions on Engineering and Technology Education. 14(2), 231-244.

[17] Choi, E. M. (2013). Applying inverted classroom to software engineering education. International Journal of e-Education, eBusiness, e-Management and e-Learning, 3(2), 121-- - 125.

[18] Davis, C. (1995). An expensive extravagance. ELT Journal 49(4), 329-36.

[19] Day, R., \& Park, J. (2005). Developing reading comprehension questions. Reading in Foreign Language, 17(1), 60 - 73. 
[20] de Jong, T. (2010). Cognitive load theory, educational research, and instructional design: Some food for thought. Instructional Science, 38, 105-134.

[21] Dorn, J., \& Soffos, L. C. (2005). Teaching for deep comprehension.UK: Stenhouse Publishers.

[22] Duffy, G. G. (2009). Explaining reading: A resource for teaching concept, skills, and strategies. New York: The Guildford Press.

[23] Elley, W.B., \& Mangubhai, I. (1983). The impact of reading on second language learning. Reading Research Quarterly, 1(9), 53-67.

[24] Finkel, E. (2012). Flipping the script in K12. District Administration Magazine, 48(10), 28 - 34.

[25] Fulton, K. (2012). Upside down and inside out: Flip your classroom to improve student learning. Learning \& Leading with Technology, 39(8), 12-17.

[26] Fulton, K. (2012). Upside down and inside out: Flip your classroom to improve student learning. Learning and Leading with Technology, 38(9), 12-17.

[27] Garrison, D. R., \& Kanuka, H. (2004). Blended learning: uncovering its transformational potential in higher education. The Internet and Higher Education, 7(2), 95-105.

[28] Gecer, A., \& Dag, F. (2012). A blended learning experience. Educational Sciences: Theory and Practice, 12(1), $438-442$.

[29] Gilboy, M., Heinerichs, S., \& Pazzaglia, G. (2015). Enhancing student engagement using the flipped classroom. Journal of Nutrition Education and Behavior, 47, 5, 109-114.

[30] Goodwin, B., \& Miller, K. (2013). Evidence on flipped classrooms is still coming in. Educational Leadership, 70(6), 78-80.

[31] Grabe, W. (2004). Research on the teaching reading. Annual Review of Applied Linguistics, 24(5), 44-69.

[32] Grabe, W. (2009). Reading in a second language: Moving from theory to practice. New York: Cambridge University Press.

[33] Harmer, J. (2000). The practice of English language teaching. London: Longman.

[34] Hashemifardnia, A., Namaziandost, E., \& Sepehri, M. (2018). The effectiveness of giving grade, corrective feedback, and corrective feedback-plus-giving grade on grammatical accuracy. International Journal of Research Studies in Language Learning, 8 (1), 15-27.

[35] Hashemifardnia, A., Namaziandost, E., Shafiee, S. (2018). The Effect of Implementing Flipped Classrooms on Iranian Junior High School Students' Reading Comprehension. Theory and Practice in Language Studies, 8(6), 665-673.

[36] Herreid, C. F., \& Schiller, N. A. (2013). Case studies and the flipped classroom. Journal of College Science Teaching, 42(5), 62-66.

[37] Hertz, M. B. (2012). The flipped classroom: Pro and con. Retrieved August 10, 2019 http://www.edutopia.org/blog/flippedclassroom-pro-and-con-mary-beth-hertz.

[38] Hosseini, E. Z., Nasri, M., \& Afghari, A. (2017). Looking beyond teachers' classroom behavior: novice and experienced EFL teachers' practice of pedagogical Knowledge to Improve Learners' Motivational Strategies. Journal of Applied Linguistics and Language Research, 4(8), 183-200

[39] Hughes, A. (2003). Testing for language teachers (2nd ed.). Cambridge: Cambridge University Press.

[40] Hung, H. T. (2015). Flipping the classroom for English language learners to foster active learning. Computer Assisted Language Learning, 28(1), 81-96.

[41] Johnson, L. W., \& Jeremy, R. (2012). Effect of the flipped classroom model on a secondary computer applications course: Student and teacher perceptions, questions and student achievement. PhD Dissertation. University of Loiusville. Retrieved Nevember 7, 2017 from https://theflippedclassroom.files.wordpress.com/2012/0 4/Johnson-renner-2012 Pdf. Web. 20 Nov. 2015.

[42] Keshmirshekan, M. H., Namaziandost, E., \& Pournorouz, M. (2019). The Impacts of Creative Writing Activities on Iranian EFL Learners' Progress in Writing, Writing Dispositions: Focus on Attitude to English Course. EPH - International Journal of Educational Research, 3(9), 12-22.

[43] Khan, S. (2012). The one world schoolhouse. Education reimagined. New York: Twelve.

[44] Kim, J., Park, H., Jang, M., \& Nam, H. (2017). Exploring flipped classroom effects on second language learners' cognitive processing. Foreign Language Annals, 50(2), 260-284.

[45] Kronholz, J. (2012). Can Khan move the bell curve to the right? Education Digest, 78(2), 23-30.

[46] Lack, K. A. (2013). Current status of research on online learning in postsecondary education. Retrieved May 12, 2017, from http://sr.ithaka.org/research-- - publications/current-status-research - online - learning postsecondary education.

[47] Lawless, K. A., \& Kulikowich, J. M. (1996). Understanding hypertext navigation through cluster analysis. Journal of Educational Research, 14, 385-399.

[48] Lewis, J. S., \& Harrison, M. A. (2012). Online delivery as a course adjunct promotes active learning and student success. Teaching of Psychology, 39(1), 72 - 76.

[49] Lindsay, C., \& Knight, P. (2006). Learning and teaching English. Oxford: Oxford University Press.

[50] Lisa, W., \& Jeremy, R. (2012). Effect of the flipped classroom model on a secondary computer applications course: Student and teacher perceptions, questions and student achievement. $\mathrm{PhD}$ Disertation. University of Loiusville. Retrieved from https://theflippedclassroom.files.wordpress.com/2012/0 4/Johnson-renner-2012 Pdf. Web. 20 Nov. 2017.

[51] Love, B., Hodge, A., Grandgenett, N., \& Swift, A. W. (2014). Student learning and perceptions in a flipped linear algebra course. International Journal of Mathematical Education in Science and Technology, 45, 2, 317-324.

[52] Lovett, M., Meyer, O., \& Thille, C. (2008). The Open Learning Initiative: Measuring the effectiveness of the OLI statistics course in accelerating student learning. Journal of Interactive Media in Education, 5, 66-79.

[53] Marlowe, A. (2012). The effect of the flipped classroom on student achievement and stress. Comparison of learning activity in a traditional classroom and a flip classroom that used an intelligent tutoring system. PhD Thesis. The Ohio State University. Retrieved from https://eld.ohiolink.edu>...html.Web. 20 Nov 2015. MSc. Thesis. Montana State University. Retrieved from https://scholarworks.montana.edu/xmlui/bitstream/han dle/1/1790/marloweC0812.pdf?sequence=1.Web. 20 Nov. 2015.

[54] Mason, G. S., Shuman, T. R., \& Cook, K. E. (2013). Comparing the effectiveness of an inverted classroom to a traditional classroom in an upper-- - division engineering course. IEEE Transactions on Education. Retrieved August 25, 2013, from 
http://ieeexplore.ieee.org/xpl/login.jsp?tp=\&arnumber=6481483\&url=http\%3A\%2F\%2Fieeexplore.ieee.org\%2Fxpls\%2Fabs_al 1.jsp\%3Farnumber\%3D6481483.

[55] Maureen, J., Glenn, J., \& Michael, T. (2002). Inverting the classroom: A gateway to creating an inclusive learning environment. 2000. Web. 26 February 2016.https://dl.dropboxusercontent.com/u/249331/Inverted_Classroom_Paper.pdf.

[56] McLaughlin, J. E., Roth, M. T., Glatt, D. M., Gharkholonarehe, N., Davidson, C. A., Griffin, L. M., Esserman, D. A., \& Mumper, R. J. (2013). The flipped classroom: A course redesign to foster learning and engagement in a health professions school. Academic Medicine, 89(2), 236-243.

[57] Michael, J. (2006). Where's the evidence that active learning works? Advances in Physiology Education, 30(6), $159-167$.

[58] Mirshekaran, R., Namaziandost, E., \& Nazari, M. (2018). The Effects of topic interest and L2 proficiency on writing skill among Iranian EFL learners. Journal of Language Teaching and Research, 9(6), 1270-1276.

[59] Moranski, K., \& Henery, A. (2016). Helping learners to orient to the inverted or flipped language classroom: Mediation via informational video. Foreign Language Annals, 50(2), 285-305

[60] Moranski, K., \& Kim, F. (2016). Flipping lessons in a multi-section Spanish course: Implications for assigning explicit grammar instruction outside of the classroom. Modern Language Journal, 100 (7), 830-852.

[61] Namaziandost E., \& Nasri, M. (2019). A meticulous look at Long's (1981) interaction hypothesis: does it have any effect on speaking skill? Journal of Applied Linguistics and Language Research, 6(2), 218-230.

[62] Namaziandost, E., \& Ahmadi, S. (2019). The assessment of oral proficiency through holistic and analytic techniques of scoring: A comparative study. Applied Linguistics Research Journal, 3(2), 70-82.

[63] Namaziandost, E., \& Ahmadi, S., Keshmirshekan, M. H. (2019). Listening comprehensions problems and strategies used by intermediate EFL learners. Journal of English Literature and Cultural Studies (JELCS Journal), 2(3), 28-41.

[64] Namaziandost, E., \& Nasri, M., Rahimi Esfahani, F., \& Keshmirshekan M. H. (2019). The impacts of spaced and massed distribution instruction on EFL learners' vocabulary learning. Cogent Education, 6: 1661131. https://doi.org/10.1080/2331186X.2019.1661131.

[65] Namaziandost, E., Abedi, P., \& Nasri, M. (2019). The role of gender in the accuracy and fluency of Iranian upper-intermediate EFL learners' 12 oral productions. Journal of Applied Linguistics and Language Research, 6(3), 110-123

[66] Namaziandost, E., Nasri, M., \& Keshmirshekan, M. H. (2019). Cohesive conjunctions in applied linguistics research articles among Iranian and non-Iranian researchers: A comparative corpus-based study. Journal of English Language Studies, 4(2), 101 $-119$.

[67] Namaziandost, E., Nasri, M., \& Rahimi Esfahani, F. (2019). Pedagogical efficacy of experience-based learning (EBL) strategies for improving the speaking fluency of upper-intermediate male and female Iranian EFL students. International Journal of Research in English Education, 4(2), 29-41.

[68] Namaziandost, E., Nasri, M., \& Rahimi Esfahani, F. (2019). Texts with various levels of hardness, reading comprehension and reading motivation: I+1 versus I-1. ELT Forum: Journal of English Language Teaching, 8(1), 60-77

[69] Namaziandost, E., Rahimi Esfahani, F., Nasri, M., \& Mirshekaran, R. (2018). The effect of gallery walk technique on Preintermediate EFL learners' speaking skill. Language Teaching Research Quarterly, 8, 1-15.

[70] Nasri, M. \& Biria, R. (2017). Integrating multiple and focused strategies for improving reading comprehension and 12 lexical development of Iranian intermediate EFL learners. International Journal of Applied Linguistics \& English Literature, 6(1), 311-321.

[71] Nasri, M., Biria, R., \& Karimi, M. (2018). Projecting Gender Identity in Argumentative Written Discourse. International Journal of Applied Linguistics \& English Literature, 7(3), 201-205.

[72] Nasri, M., Namaziandost, E., \& Akbari, S. (2019). Impact of pictorial cues on speaking fluency and accuracy among Iranian pre-intermediate EF learners. International Journal of English Language and Literature Studies, 8(3), 99-109.

[73] Nation, I.S.P. (1993). Vocabulary size, growth and use. The Bilingual Lexicon. 115-134. Eds. R. Schreuder, B. Weltens, Amsterdam/Philadelphia: John Benjamins.

[74] Nation, I.S.P. (2009). Teaching ESL/EFL reading and writing. New York: Routledge.

[75] Nuttal, C. (1996). Teaching reading skills in a foreign language. New Edition, 127. Heinemann.

[76] Overmyer, G. (2014). The flipped classroom model for college algebra: effects on student achievement. PhD Dissertation. Colorado State University. Retrieved from https://flippedlearning.org.cms/lib07/Va01...html.Pdf. Web. 20 Nov.2015.

[77] Ozbay, M. (2006). Turkish primary schools questions: understanding the contribution of students' thinking skills. Dergisi, 4(5), 539-546.

[78] Pierce, R. \& Fox, J. (2012). Vodcasts and active - learning exercises in a "flipped classroom" model of a renal pharmacotheraphy module. American Journal of Pharmaceutical Education, 76(10), 181-196.

[79] Popyack, J. (2003). Computer programming course redesign. National Center for Academic Transformation (NCAT). Retrieved August 10, 2019, from http://www.thencat.org/PCR/R3/DU/DU_Overview.htm.

[80] Pressley, M. (2000). What should comprehension instruction be the instruction of? In M. L. Kamil, P. B. Mosenthal, P. D. Pearson, \& R. Barr (Eds.), Handbook of reading research (vol. 3), 545-562. Mahwah, NJ: Erlbaum

[81] Riffell, S., \& Sibley, D. (2005). Using web-- - based instruction to improve large undergraduate biology courses: an evaluation of a hybrid course format. Computers \& Education, 44(3), 217-235.

[82] Robert Overmyer, G. (2014). The flipped classroom model for college algebra: Effects on student achievement. PhD Dissertation. Colorado State University. Retrieved Nevember $11, \quad 2017$ from https://flippedlearning.org.cms/lib07/Va01...html.Pdf.

[83] Sadaghiani, S. (2012). Overcoming dyslexia. New York: Alfred A. Knopf. Sparks, R. (2013). The acquisition of academic literacy in a second language: A longitudinal case study. Written Communication, 14(1), 3-62.

[84] Schmidt, R., \& Richards, J. (2002). Attention. In Robinson, Peter (ed.). Cognition and second language instruction (3-32). Cambridge: Cambridge University Press. 
[85] Schmidt, Y. (1990). Reading writing connection for EFL college learners' literacy development. Asian EFL Journal, 11(1), 6879.

[86] Spencer, D., Wolf, D., \& Sams, A. (2011). The flipped class: Are you ready to flip? Retrieved August 10, 2019, from http://www.thedailyriff.com/articles/are-you-ready-to-flip-691.php.

[87] Stone, B. B. (2012). Flip your classroom to increase active learning and student engagement. 28th annual conference on distance teaching and learning. Retrieved August 25, 2017, from http://www.uwex.edu/disted/conference/Resource_library/proceedings/56511_2012.pdf.

[88] Strayer, J. F. (2012). How learning in an inverted classroom influences cooperation, innovation and task orientation. Learning Environments Research, 15(2), 171-193.

[89] Susser, B., \& Robb, T. (1990). EFL extensive reading instruction: Research and procedure. JALT Journal, 12(2), 161-185.

[90] Sweller, J. (2007). Evolutionary biology and educational psychology. In J. S. Carlson \& J. R. Levin (Eds.), Psychological perspectives on contemporary educational issues (pp. 165-175). Greenwich, CT: Information Age.

[91] Szparagowski, R. (2014). The effectiveness of the flipped classroom. Honors Projects, 5, 1-31.

[92] Tahmasbi, S., Hashemifardnia, A., \& Namaziandost, E. (2019). Standard English or world Englishes: Issues of ownership and preference. Journal of Teaching English Language Studies, 7(3), 83-98.

[93] TechSmith (2015). Ditching anxiety: Flipping for lower anxiety and increase AP calculus scores. Retrieved August 10, 2019, from http://youtu.be/8IvjH4aiCeY

[94] Thakur, G. (2015). Flipped classroom new approach to learning. Recent trends in ICT in education. Laxmi Book Publication. Maharashtra.

[95] Tompkins, G. E. (2011). Literacy for the 21st century: A balanced approach (4 ed.). Upper Saddle River, NJ: Pearson, Merrill, Prentice Hall.

[96] Villa, R. (1994). Content area reading: Literacy and learning across the curriculum. New York: Longman

[97] Walker, Y. (2011). External variables affecting language learning strategies of Japanes EFL learners: Effects of entrance examination, years spent at college/university, and staying overseas. Unpublished master's thesis, Lancaster University, Lancaster, England.

[98] Zhao, Y.R., \& Breslow, L. (2013). Literature review on hybrid/blended learning. Unpublished manuscript, HarvardX, Harvard University, Cambridge, MA.

Leila Neisi was born in Ahvaz, Iran. She holds a master's degree in TEFL from Islamic Azad University of Ahvaz. Here areas of interest are linguistics, language skills and discourse analysis.

Mehrnnoosh Hajijalili was born in Isfahan Province of Iran. She holds an MA degree in TEFL from University of Isfahan. Her main interests of research are language skills and EFL teaching. His research papers have been published by various international journals.

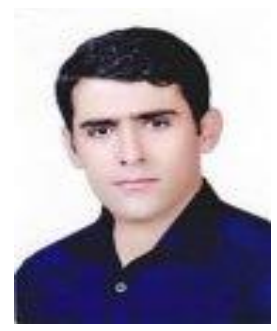

Ehsan Namaziandost was born in Shiraz Province of Iran in 1985. He holds an MA degree in TEFL from Islamic Azad University of Ahvaz. Now, he is Ph.D. candidate of TEFL at Islamic Azad University, Shahrekord, Iran. His main interests of research are second language acquisition, EFL teaching and testing, teaching language skills, and language learning strategies. His research papers and articles have been published by different international journals. 